\title{
Impact of Hydrogen Ion Concentration on Amino Acids Composition of Macadamia Protein: Approached Using Cation-Exchange Chromatography
}

\author{
Jianzhi Ye ${ }^{1}$, Zhiping Han ${ }^{1}$, Wei Tan ${ }^{2}$ \\ ${ }^{1}$ Agricultural Product Processing Research Institute, Chinese Academy of Tropical Agricultural Sciences, Zhanjiang, China \\ ${ }^{2}$ National Center of Agricultural Standardization and Supervision, Hefei, China \\ Email:904506892@qq.com
}

How to cite this paper: Ye, J.Z., Han, Z.P. and Tan, W. (2016) Impact of Hydrogen Ion Concentration on Amino Acids Composition of Macadamia Protein: Approached Using Cation-Exchange Chromatography. Journal of Biosciences and Medicines, 4, 6-14. http://dx.doi.org/10.4236/jbm.2016.410002

Received: August 4, 2016

Accepted: October 9, 2016

Published: October 12, 2016

Copyright $\odot 2016$ by authors and Scientific Research Publishing Inc. This work is licensed under the Creative Commons Attribution International License (CC BY 4.0).

http://creativecommons.org/licenses/by/4.0/

\section{(c) (i) Open Access}

\begin{abstract}
In the present context, the objective of this study was to synthesize and analyze the content of AA of macadamia protein and the impact of hydrogen ion concentration $(\mathrm{pH})$ on AA composition. The determination of AA mainly by cation-exchange chromatography was also investigated. Reproducible and reliable techniques for quantification and identification of AA usually require derivatization. However, techniques such as AA analyzer are composed of cation-exchange chromatography and other components can sideline the derivatization with significant accuracy. The present analysis revealed a higher concentration of essential amino acids especially acidic AA, Glu and Asp and basic AA, Arg than other AA in macadamia protein. The study constitutes first report of use of bubble chart for evaluation of AA and explaination of AAS. The results may elaborate that the degradation of AA of macadamia protein for extraction of $\mathrm{pH} 11$ is caused by the impact of $\mathrm{pH}$. Moreover, the nutritional values of AA present in macadamia protein could change for the better by adjusting $\mathrm{pH}$ of extraction.
\end{abstract}

\section{Keywords}

Amino Acids, Hydrogen Ion Concentration, Macadamia Protein, Cation-Exchange Chromatography

\section{Introduction}

Macadamia nuts as a natural healthy and nutritious food contain no cholesterol and are 
a good source of protein [1]. With high nutritional quality, they are gradually aroused the attention of consumers and industries described in Figure 1. And the residue of macadamia nuts after extracting oil also exhibits considerable quantities of protein, with many essential and non essential amino acids. It is therefore necessary to obtain protein to increased value of macadamia nut by-products for economic and environmental reasons.

Amino acids are the building blocks (monomers) of proteins, and 20 different amino acids are used to synthesize proteins. Those requirements in humans were even emphasized on the metabolic availability of amino acids investigated by Rajavel et al. (2009) [2]. The cellular amino acid composition obtained by amino acid analysis of whole cells, differs such as eubacteria, protozoa, fungi and mammalian cells. These results suggest that the difference in the cellular amino acid composition reflects biological changes as the result of evolution [3] [4]. In the food industry, several junctions of quinone-amino acids influences the colour, taste, and aroma of foods. Physiological and physical phenomena such as formation of humic substances, discoloration of plants during processing, browning of foods, alteration of digestibility and solubility, germicidal activity, cytotoxicity and more occur when quinones from disintegrating cells meet amino acids [5]. Although recent studies indicate extensive catabolism of amino acids by the portal-drained viscera of humans, Yin et al. (2010) found measurements of the entry of dietary amino acids into the portal circulation which quantify in vivo absorption and metabolism of dietary amino acids [6]. In light of these considerations, amino acids play an important role in protein metabolism in humans [7].

Many methods and approaches have been used for determination of amino acids, such as gas chromatography-mass spectroscopy [8] [9], capillary electrophoresis-mass spectroscopy [10], liquid chromatography-mass spectroscopy [11], continuous wavelet transform and principal component analysis [12], dual choice feeding tests [13] and many other complicated methods. These methods and approaches either require derivatization of amino acids or waste laborious and fail to determine some amino acids [14]. Moreover, derivatization adversely affects class of compounds and may hamper its identification [11].

In the present context, the content of amino acids of macadamia protein and the

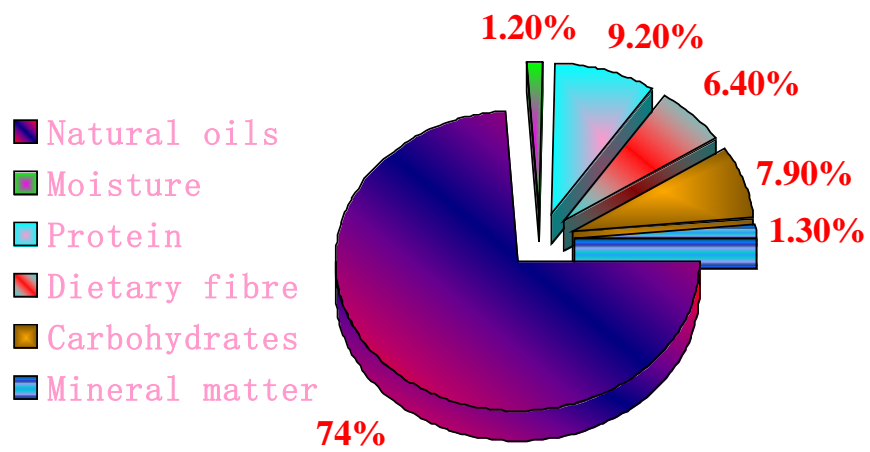

Figure 1. The nutritious composition of both raw, dried and roasted macadamias. 
impact of hydrogen ion concentration $(\mathrm{pH})$ on amino acids composition were investigated. The determination of amino acids was mainly relied upon cation-exchange chromatography.

\section{Experimental}

\subsection{Materials and Equipments}

The residue of Macadamia after extracting oil were obtained from Key Laboratory of Tropical Crop Products Processing Ministry of Agriculture in China (our own laboratory). Hydrochloric acid $(\mathrm{HCl})$ and sodium hydroxide $(\mathrm{NaOH})$ were procured from Guangdong Guanghua Chemical Factory Co., Ltd. (China). HH-W600 electric heated water bath, 752N spectrophotometer, electronic balance, PHS- 25 acidity meter, circulating water vacuum pump and low-speed desktop centrifuge were used in this experiment. All other chemicals used were analytical grade for the experiments and analysis.

\subsection{Preparation of Macadamia Protein}

Box-Behnken Design (BBD) was used to estimate and optimize the experiment for improving the yield of protein. The optimum parameters were materials to water ratios 1 : 91, extraction time $2.5 \mathrm{~h}$, extraction temperature $55^{\circ} \mathrm{C}$ and $\mathrm{pH} 9.0$. Under the optimized conditions, macadamia protein was extracted and centrifuged at $5000 \mathrm{rpm}$ for $10 \mathrm{~min}$. Then the supernatant was collected and and $\mathrm{pH}$ was adjusted to 4.6 to precipitate protein. After incubation at room temperature for one hour, the content was centrifuged again at $5000 \mathrm{rpm}$ for $10 \mathrm{~min}$ and the supernatant was discarded. The protein left in the centrifuge tubes was freezing dried. Parallel experiments were conducted with extraction at $\mathrm{pH}$ 11. Extracted proteins before and after freezing dried could be found in Figure 2.

\subsection{Cation-Exchange Chromatography Parameters}

The analysis was carried out in a column packed with $4.6 \mathrm{~mm} \mathrm{ID} \star 60 \mathrm{~mm}$ Hitachi custom

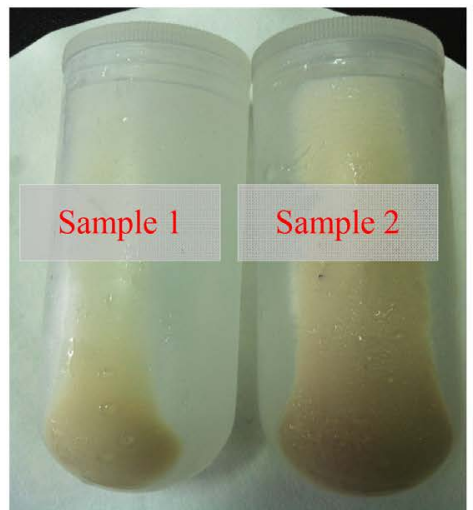

(a)

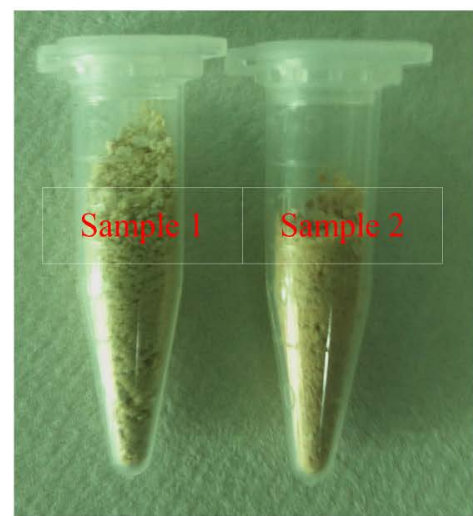

(b)

Figure 2. Extracted proteins from macadamia. (a) Wet extracted proteins; (b) Freezeing dried extracted proteins. Sample 1: extraction at $\mathrm{pH}$ 9, sample 2: extraction at $\mathrm{pH} 11$. 
ion exchange resin and connected with EZChrom Elite software. Analysis time: $30 \mathrm{mi}-$ nutes approximately; Reproducibility of peak retention time: CV $0.3 \%$ (Arg), 0.5\% (Ala); Reproducibility of peak area: CV 1.0\% (Gly, His); Detection limit: 3 pmol (S/N = 2, Asp); Spectrophotometer: Aplanatic concave diffraction grating with $570 \mathrm{~nm}$ and 440 nm Analyzer; CPU: 32 bits OS, Windows xp; Operating temperature range: $15^{\circ} \mathrm{C}$ to $35^{\circ} \mathrm{C}$; Power supply: 100 - $115 \mathrm{~V} \mathrm{AC/220} \mathrm{-} 240 \mathrm{~V} \mathrm{AC,} 800 \mathrm{VA}$ and over, w/in 50/60 Hz \pm $0.5 \mathrm{~Hz}$; 2 gas source must be prepared. Amino Acid Analyzer is composed of these parameter and components.

\subsection{Statistical Analysis}

All experiments were performed in triplicate, and statistical analysis of the biological replicates was conducted using Excel or OriginPro 8.5 (www.originlab.com).

The content of amino acids was explained by the following formula:

$$
\text { Amino acid content }(\%)=\frac{A_{1} \times C_{0}}{A_{0}} \times \frac{N \times M \times 100}{W \times 10^{6}}
$$

where $A_{1}, A_{0}$ represent the peak area of amino acid in sample and standard, respectively; $C_{0}$ is the concentration of amino acids in sample (nmol/20 $\mu$ l); $N$ : dilution multiple of sample; $M$ : molecular weight of amino acid; $W$ : mass of sample.

The amino acids scores was explained according to the following formula:

$$
\text { Amino acids scores }=\frac{A}{B} \times 100
$$

where $A$ : content of essential amino acid in sample; $B$ : content of essential amino acid in the FAO/WHO pattern (1973) [15].

\section{Results and Discussion}

\subsection{Cation-Exchange Chromatography Analysis}

There was no significant difference in the amino acids analysis of the first and second protein samples from extraction at $\mathrm{pH} 9$ or $\mathrm{pH} 11$. The content of amino acids of macadamia protein and the impact of $\mathrm{pH}$ on amino acids composition were investigated in Table 1 and Table 2 . The cation-exchange chromatography analysis of the protein samples of $\mathrm{pH} 9$ revealed the AA profile with contribution of 18 AA including 7 essential (Tryptophan was not detectable) and rest non-essential amino acids. The content of 18 AA quantified by cation-exchange chromatography ranged between 6.31 and 164.35 $\mathrm{mg} / \mathrm{g}$ according to formula 1 (Table 1 ). The highest content was of Glu $164.35 \mathrm{mg} / \mathrm{g}$ followed by Arg $117.77 \mathrm{mg} / \mathrm{g}$, Asp $96.72 \mathrm{mg} / \mathrm{g}$ and Gly $67.19 \mathrm{mg} / \mathrm{g}$. It is noticeable that both the acidic amino acids, Glu and Asp and basic amino acid, Arg were among the dominant contributors. And the essential AA, Leu $(64.84 \mathrm{mg} / \mathrm{g})$ is present in almost twice amount than the other essential AA quantified (Thr 30.36, Val 37.14, Met 6.31, Ile 29.60, Phe 28.32, Lys $28.06 \mathrm{mg} / \mathrm{g}$ ). Even though the amount of Trp was not detectable for the method of determination, the relatively high content of AA is much more than amaranth's [11]. SD of the data was analyzed by Microsoft Excel software and P-value < 
Table 1. Amino acids analysis of proteins extracted at $\mathrm{pH} 9$.

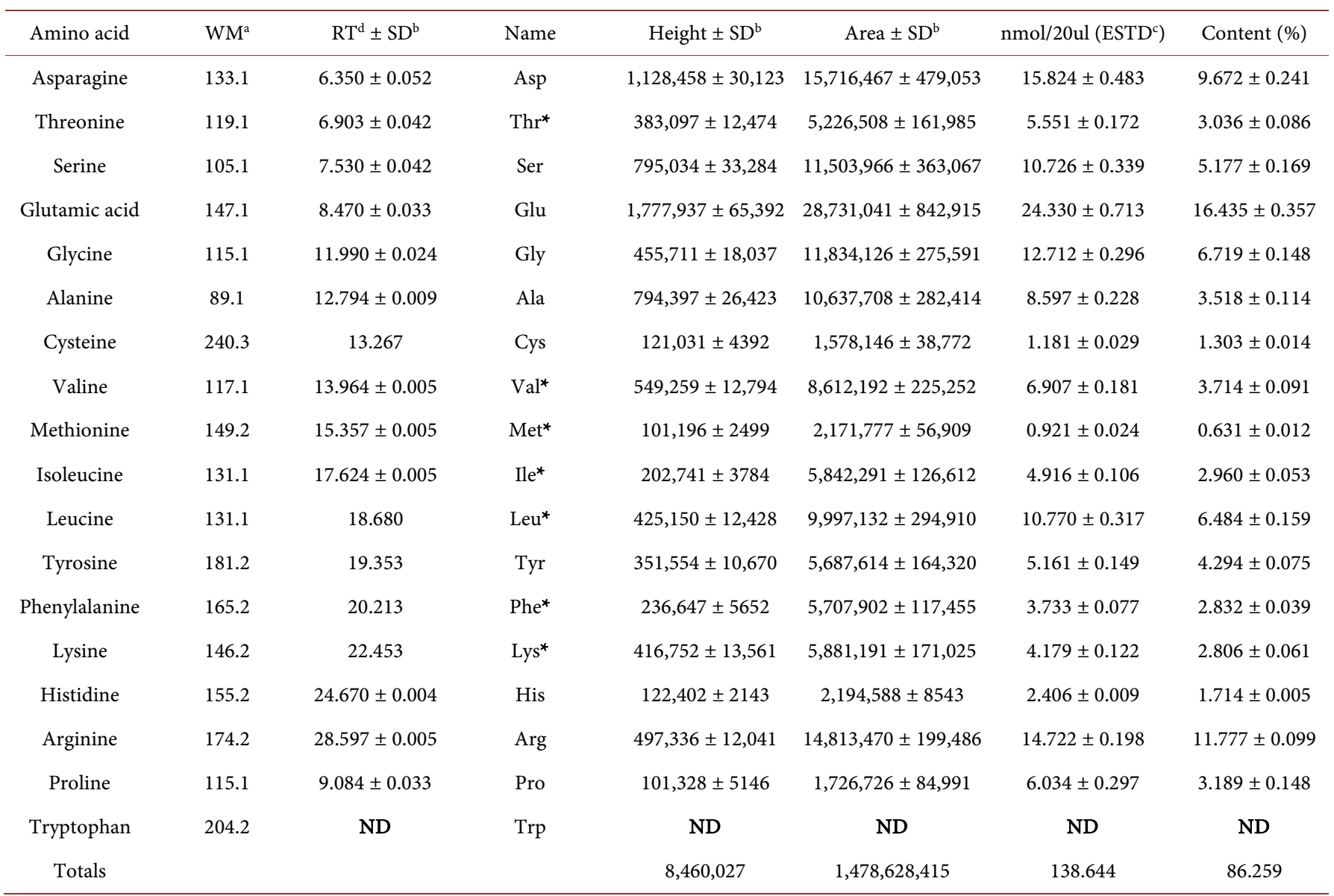

${ }^{\mathrm{a}}$ WM: Molecular weight of amino acid; ${ }^{\mathrm{b}}$ SD: Standard deviation; ${ }^{\mathrm{C}}$ ESTD: External standard method; ${ }^{\mathrm{d}} \mathrm{RT}$ : Retention Time; ${ }^{*}$ : Essential amino acids; ND: Not detectable; ${ }^{*}$-value $<0.05$. Data represent mean \pm SD (3 biological replicates).

0.05 .

The cation-exchange chromatography analysis of the protein samples of $\mathrm{pH} 11$ revealed the content of 18 AA quantified by cation-exchange chromatography ranged between 4.38 and $117.18 \mathrm{mg} / \mathrm{g}$, and the highest content was of Glu $117.18 \mathrm{mg} / \mathrm{g}$ followed by Arg $78.72 \mathrm{mg} / \mathrm{g}$, Asp $63.58 \mathrm{mg} / \mathrm{g}$ and Gly $45.47 \mathrm{mg} / \mathrm{g}$ (Table 2). Also it is noticeable that both the acidic amino acids, Glu and Asp and basic amino acid, Arg were among the dominant contributors. And the essential AA, Leu $(44.45 \mathrm{mg} / \mathrm{g})$ is present in almost twice amount than the other essential AA quantified (Thr 22.31, Val 25.34, Met 4.38, Ile 20.45, Phe 21.51, Lys $19.63 \mathrm{mg} / \mathrm{g}$ ). The content of all AA reducted substantially, compared with reported in above-mentioned studies. These data support the results that the degradation of AA of macadamia protein for extraction of $\mathrm{pH} 11$ is caused by the impact of $\mathrm{pH}$.

\subsection{Evaluation of $\mathrm{AA}$}

Conformationally, constrained amino acids are a useful way of tailoring the rigidity of peptides [16]. Rafiemanzelat et al. (2012) have developed a degradable monomer based 
Table 2. Amino acids analysis of proteins extracted at $\mathrm{pH} 11$.

\begin{tabular}{|c|c|c|c|c|c|c|c|}
\hline Amino acid & $\mathrm{WM}^{\mathrm{a}}$ & $\mathrm{RT}^{\mathrm{d}} \pm \mathrm{SD}^{\mathrm{b}}$ & Name & Height $\pm \mathrm{SD}^{\mathrm{b}}$ & Area $\pm S D^{b}$ & $\mathrm{nmol} / 20 \mathrm{ul}\left(\mathrm{ESTD}^{\mathrm{c}}\right)$ & Content (\%) \\
\hline Asparagine & 133.1 & $6.347 \pm 0.057$ & Asp & $698,892 \pm 32,892$ & $9,748,698 \pm 414,652$ & $9.815 \pm 0.417$ & $6.358 \pm 0.417$ \\
\hline Threonine & 119.1 & $6.907 \pm 0.057$ & Thr* & $260,327 \pm 13,711$ & $3,623,733 \pm 165,286$ & $3.849 \pm 0.176$ & $2.231 \pm 0.176$ \\
\hline Serine & 105.1 & $7.527 \pm 0.047$ & Ser & $479,449 \pm 30,358$ & $6,945,418 \pm 292,983$ & $6.476 \pm 0.274$ & $3.312 \pm 0.274$ \\
\hline Glutamic acid & 147.1 & $8.467 \pm 0.037$ & Glu & $1,196,464 \pm 68,461$ & $19,329,519 \pm 730,629$ & $16.369 \pm 0.619$ & $11.718 \pm 0.619$ \\
\hline Glycine & 115.1 & $11.990 \pm 0.033$ & Gly & $294,886 \pm 16,445$ & $7,557,786 \pm 231,760$ & $8.118 \pm 0.249$ & $4.547 \pm 0.249$ \\
\hline Alanine & 89.1 & $12.797 \pm 0.005$ & Ala & $567,213 \pm 27,605$ & $7,605,155 \pm 231,748$ & $6.147 \pm 0.187$ & $2.665 \pm 0.187$ \\
\hline Cysteine & 240.3 & 13.273 & Cys & $84,715 \pm 2190$ & $1,137,223 \pm 16,612$ & $0.851 \pm 0.012$ & $0.995 \pm 0.012$ \\
\hline Valine & 117.1 & $13.970 \pm 0.004$ & $\mathrm{Val}^{*}$ & $361,025 \pm 15,981$ & $5,544,967 \pm 190,768$ & $4.447 \pm 0.153$ & $2.534 \pm 0.152$ \\
\hline Methionine & 149.2 & 15.367 & Met* & $67,361 \pm 3190$ & $1,422,654 \pm 59,294$ & $0.604 \pm 0.025$ & $0.438 \pm 0.025$ \\
\hline Isoleucine & 131.1 & $17.644 \pm 0.005$ & $\mathrm{Ile}^{*}$ & $132,890 \pm 5524$ & $3,808,508 \pm 141,624$ & $3.205 \pm 0.120$ & $2.045 \pm 0.120$ \\
\hline Leucine & 131.1 & $18.710 \pm 0.004$ & Leu $^{*}$ & $284,259 \pm 11,044$ & $6,467,194 \pm 265,396$ & $6.967 \pm 0.286$ & $4.445 \pm 0.286$ \\
\hline Tyrosine & 181.2 & $19.360 \pm 0.010$ & Tyr & $234,290 \pm 9142$ & $3,774,921 \pm 139,195$ & $3.425 \pm 0.126$ & $3.020 \pm 0.126$ \\
\hline Phenylalanine & 165.2 & $20.220 \pm 0.010$ & $\mathrm{Phe}^{*}$ & $168,127 \pm 6912$ & $4,090,728 \pm 129,761$ & $2.675 \pm 0.085$ & $2.151 \pm 0.085$ \\
\hline Lysine & 146.2 & $22.450 \pm 0.014$ & Lys* & $276,786 \pm 12224$ & $3,882,139 \pm 151,657$ & $2.759 \pm 0.108$ & $1.963 \pm 0.108$ \\
\hline Histidine & 155.2 & $24.677 \pm 0.014$ & His & $74,571 \pm 1203$ & $1,233,249 \pm 9257$ & $1.352 \pm 0.011$ & $1.021 \pm 0.011$ \\
\hline Arginine & 174.2 & $28.620 \pm 0.010$ & Arg & $322,733 \pm 6858$ & $9,344,176 \pm 83,756$ & $9.286 \pm 0.083$ & $7.872 \pm 0.083$ \\
\hline Proline & 115.1 & $9.083 \pm 0.042$ & Pro & $66,692 \pm 5478$ & $1,143,911 \pm 83,046$ & $3.997 \pm 0.290$ & $2.239 \pm 0.290$ \\
\hline Tryptophan & 204.2 & ND & $\operatorname{Trp}$ & ND & ND & ND & ND \\
\hline Totals & & & & $5,570,675$ & $96,659,974$ & 90.3375 & 59.55341 \\
\hline
\end{tabular}

${ }^{\mathrm{a}}$ WM: Molecular weight of amino acid; ${ }^{\mathrm{b}} \mathrm{SD}$ : Standard deviation; ${ }^{\mathrm{c} E S T D}$ : External standard method; ${ }^{\mathrm{d}} \mathrm{RT}$ : Retention Time; ${ }^{*}$ : Essential amino acids; ND: Not detectable; ${ }^{*} \mathrm{P}$-value $<0.05$. Data represent mean $\pm \mathrm{SD}$ (3 biological replicates).

on $\alpha$-amino acid to accelerate hard segment degradation [17]. Additional amino acids in cyclic tetrapeptides are supposed to play important role for effectively inhibiting the histone deacetylases [18]. Thus, the synthes and evaluation of AA play a crucial role in the utilization of AA.

In order to evaluate the degradation of AA of macadamia protein caused by the impact of $\mathrm{pH}$, we introduced this new bubble chart for explaination of AAS. The absence of some essential AA in protein causes other AA difficult to be fully utilized and the overall protein digestibility was reduced. Therefore, nutritional value of protein in food depends on species, quantity and proportion of essential AA. The amount of essential AA, nonessential AA and total AA was also shown in the Figure 3. The amount of essential AA, nonessential AA and total AA from extraction at $\mathrm{pH} 9$ was 22.463\%, $63.796 \%$ and $86.259 \%$, respectively. And the ratio of amount of essential AA and nonessential AA, total AA was 0.35 and 0.26 , respectively. From Figure 3, for $\mathrm{pH} 9$, the AAS of Met + Cys, Ile, Thr, Leu, Val + Tyr was 55.3, 74, 75.9, 92.6, 160.1 according to formula 2. And the corresponding data for $\mathrm{pH} 11$ was 40.9, 51.1, 55.8, 63.5, 111.1. Even though the amount of the latter was less than the former, these related data was better than the AAS of FAO/WHO protein pattern. Moreover, the total AAS of $\mathrm{pH} 9$ and $\mathrm{pH}$ 11 sample was 64.2, 56.6 respectively. Although compared with AA from extraction at $\mathrm{pH} 9$, the amount of essential AA, nonessential AA and total AA from extraction at $\mathrm{pH}$ 

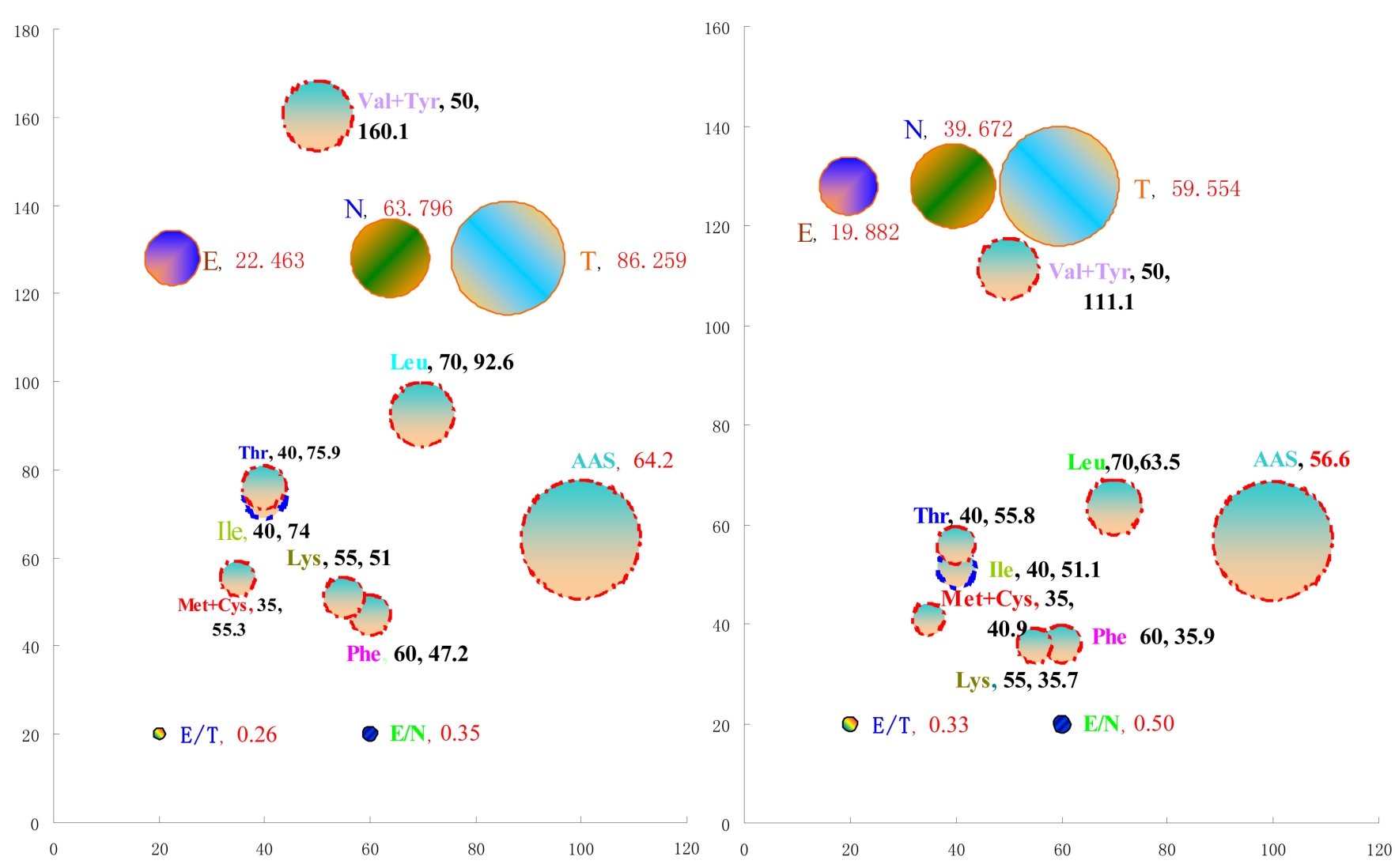

Figure 3. Evaluation of AA from extraction at $\mathrm{pH} 9$ (Left) and $\mathrm{pH}$ 11(Right) by bubble chart E, N, T: The amount of essential AA, nonessential AA and total AA respectively; E/N, E/T: The ratio of amount of essential AA and nonessential AA, total AA respectively. Centre and diameter of bubbles represent mean and SD respectively (3 biological replicates).

11 was only $19.882 \%, 39.672 \%$ and $59.554 \%$, the ratio of amount of essential AA and nonessential AA, total AA was 0.50 and 0.33 . The latter was more close to the $\mathrm{FAO} /$ WHO protein pattern of reference.

\section{Conclusion}

The objective of this study was to synthesize and analyze the content of AA of macadamia protein and the impact of hydrogen ion concentration $(\mathrm{pH})$ on AA composition. The determination of AA and its content mainly by cation-exchange chromatography was also investigated. The $\mathrm{E}, \mathrm{N}$ and $\mathrm{T}$ from extraction at $\mathrm{pH} 9$ was $22.463 \%, 63.796 \%$ and $86.259 \%$, respectively. And $\mathrm{E} / \mathrm{N}, \mathrm{E} / \mathrm{T}$ was 0.35 and 0.26 , respectively. Compared with AA from extraction at $\mathrm{pH} 9$, the $\mathrm{E}, \mathrm{N}$ and $\mathrm{T}$ from extraction at $\mathrm{pH} 11$ was only $19.882 \%, 39.672 \%$ and $59.554 \%$. However, E/N, E/T was 0.50 and 0.33 . The latter was more close to the FAO/WHO protein pattern of reference. Meanwhile, the AAS of Met + Cys, Ile, Thr, Leu, Val + Tyr and total AA was 55.3, 74, 75.9, 92.6, 160.1, 64.2 and 40.9, $51.1,55.8,63.5,111.1,56.6$ respectively. The results may elaborate that the degradation of AA of macadamia protein for extraction of $\mathrm{pH} 11$ is caused by the impact of $\mathrm{pH}$. Moreover, the nutritional value of AA present in macadamia protein could change for the better by adjusting $\mathrm{pH}$ of extraction. 


\section{References}

[1] Ghorbani, M. and Morgan, M.R.A. (2010) Protein Characterisation and Immunochemical Measurements of Residual Macadamia Nut Proteins in Foodstuffs. Food and Agricultural Immunology, 21, 347-360. http://dx.doi.org/10.1080/09540105.2010.508815

[2] Rajavel, E., Ronald, O.B. and Paul, B.P. (2009) Amino Acid Requirements in Humans: With a Special Emphasis on the Metabolic Availability of Amino Acids. Amino Acids, 1, 19-27.

[3] Giti, Emtiazi Sorimachi, K., Itoh, T., Kawarabayasi, Y., et al. (2001) Conservation of the Basic Pattern of Cellular Amino Acid Composition of Archaeobacteria during Biological Evolution and the Putative Amino Acid Composition of Primitive Life Forms. Amino Acids, 4, 393-399.

[4] Dai, Z.L., Zhang, J., Wu, G.Y. and Zhu, W.Y. (2010) Utilization of Amino Acids by Bacteria from the Pig Small Intestine. Amino Acids, 5, 1201-1215.

http://dx.doi.org/10.1007/s00726-010-0556-9

[5] Bittner, S. (2006) When Quinones Meet Amino Acids: Chemical, Physical and Biological Consequences. Amino Acids, 3, 205-224. http://dx.doi.org/10.1007/s00726-005-0298-2

[6] Yin, Y.L., Huang, R.L., Li, T.J., et al. (2010) Amino Acid Metabolism in the Portal-Drained Viscera of Young Pigs: Effects of Dietary Supplementation with Chitosan and Pea Hull. Amino Acids, 5, 1581-1587. http://dx.doi.org/10.1007/s00726-010-0577-4

[7] Fang, Z.F., Yao, K., Zhang, X.L., et al. (2010) Nutrition and Health Relevant Regulation of Intestinal Sulfur Amino Acid Metabolism. Amino Acids, 3, 633-640.

http://dx.doi.org/10.1007/s00726-010-0502-x

[8] Wood, P.L., Khan, M.A. and Moskal, J.R. (2006) Neurochemical Analysis of Amino Acids, Polyamines and Carboxylic Acids: GC-MS Quantitation of Tbdms Derivatives Using Ammonia Positive Chemical Ionization. Journal of Chromatography B, 831, 313-319. http://dx.doi.org/10.1016/j.jchromb.2005.12.031

[9] Coutts, R.T. and Yeung, J.M. (1985) Gas Chromatographic Analysis of Amino Acids. Amino Acids, 3, 29-50. http://dx.doi.org/10.1385/0-89603-077-6:29

[10] Poinsot, V., Gavard, P., Feurer, B. and Couderc, F. (2010) Recent Advances in Amino Acid Analysis by CE. Electrophoresis, 31, 105-121. http://dx.doi.org/10.1002/elps.200900399

[11] Nimbalkar, M.S., Pai, S.R. and Pawa. N.V. (2012) Free Amino Acid Profiling in Grain Amaranth Using LC-MS/MS. Food Chemistry, 134, 2565-2569. http://dx.doi.org/10.1016/j.foodchem.2012.04.057

[12] Li, Z.C., Zhou, X.B., Dai, Z., et al. (2008) Prediction of Protein Structural Classes by Chou's Pseudo Amino Acid Composition: Approached Using Continuous Wavelet Transform and Principal Component Analysis. Amino Acids, 2, 415-425.

[13] Michele, B., Piotr, M., Laura, B., et al. (2010) Amino Acid Content and Nectar Choice by Forager Honeybees (Apis mellifera L.). Amino Acids, 1, 315-318.

[14] Ventura, G., Moinard, C., Segaud, F., et al. (2010) Adaptative Response of Nitrogen Metabolism in Early Endotoxemia: Role of Ornithine Aminotransferase. Amino Acids, 5, 1417 1426. http://dx.doi.org/10.1007/s00726-010-0601-8

[15] FAO/WHO (1973) Energy and Protein Requirement. Report of Joint FAO/WHO. FAO, Geneva, 63.

[16] Reilly, E.O., Pes, L., Ortin, Y., et al. (2012) Synthesis of a Conformationally Constrained d-Amino Acid Building Block. Amino Acids.

[17] Rafiemanzelat, F., Zonouz, A.F. and Emtiazi, G. (2012) Synthesis of New Poly(ether-ure- 
thane-urea)s Based on Amino Acid Cyclopeptide and PEG: Study of Their Environmental Degradation. Amino Acids.

[18] Islam, M.S., Bhuiyan, M.P., et al. (2012) Evaluation of Functional Groups on Amino Acids in Cyclic Tetrapeptides in Histone Deacetylase Inhibition. Amino Acids, 42, 2103-2110.

\section{Abbreviations}

$\begin{array}{ll}\text { AA } & \text { Amino acids } \\ \text { pH } & \text { Hydrogen ion concentration } \\ \text { AAS } & \text { Amino acids scores } \\ \text { ID } & \text { Inside diameter } \\ \text { WM } & \text { Molecular weight } \\ \text { CV } & \text { Coefficient of variation } \\ \text { AC } & \text { Alternating current } \\ \text { WTO } & \text { World Trade Organization } \\ \text { FAO } & \text { Food and Agricultural Organization }\end{array}$

Submit or recommend next manuscript to SCIRP and we will provide best service for you:

Accepting pre-submission inquiries through Email, Facebook, LinkedIn, Twitter, etc. A wide selection of journals (inclusive of 9 subjects, more than 200 journals)

Providing 24-hour high-quality service User-friendly online submission system

Fair and swift peer-review system

Efficient typesetting and proofreading procedure

Display of the result of downloads and visits, as well as the number of cited articles Maximum dissemination of your research work

Submit your manuscript at: http://papersubmission.scirp.org/

Or contact jbm@scirp.org 